\title{
Purification and Some Properties of Protease from Aeromonas hydrophila
}

\author{
Kinya KANAI ${ }^{* 1,2}$ and Hisatsugu WAKABAYASHI ${ }^{* 11}$
}

(Accepted December 28, 1983)

\begin{abstract}
Protease was obtained from the culture filtrate of Aeromonas hydrophila by ion-exchange chromatography and gel filtration. It gave a single band on disc electrophoresis and a single precipitin line on immunoelectrophoresis. The molecular weight was estimated to be 57,500 by SDS-polyacrylamide electrophoresis, but it was estimated to be 33,000 by gel filtration. The enzyme was stable at $\mathrm{pH} 6$ to 10 , and the optimum pH for the activity was 7.5 to 8.5 . The enzyme was stable at $50^{\circ} \mathrm{C}$, but $30 \%$ of the activity was lost by heating for $1 \mathrm{~h}$ at $60^{\circ} \mathrm{C}$. Chelating agents, $\mathrm{Ni}^{2+}$, $\mathrm{Cu}^{2+}, \mathrm{Cd}^{2+}$, and $\mathrm{Hg}^{2+}$ inhibited the enzyme activity. Carp injected with $200 \mu \mathrm{g}$ of the protease per $100 \mathrm{~g}$ body weight died, showing extensive hemorrhages in the abdominal cavity. Hemorrhages and necrosis were observed in the guinea-pig skin upon intracutaneous injection of $3.13 \mu \mathrm{g}$ protease.
\end{abstract}

Aeromonas hydrophila, a gram-negative facultative anaerobic rod, has long been known as an important pathogen of freshwater fishes. ${ }^{1)}$ It is also recognized as a pathogen of warm-blooded animals, including human. ${ }^{2,8}$ This organism produces various kinds of toxic substances and enzymes, some of which have been thought to play a role in its pathogenicity. Among these substances, hemolysins and enterotoxin attract attention mainly in the field of medicine. ${ }^{4-10}$

Studies on the toxic substances produced by Aeromonas hydrophila in fish diseases were rather few. JANKOV, ${ }^{11}$ ) LobOUNTzOV and Roudikov, ${ }^{22}$ and WAKABAYASHI et al. ${ }^{13)}$ described that the culture filtrate of $A$. hydrophila had lethal activity to carp, but they did not demonstrate which substances in the culture filtrate were toxic. SHIMIZU $^{14-17)}$ reported hemorrhagic and necrotic activities of the sonicated cell extracts. The necrotic factor, which had a protein nature and possessed proteolytic activity, caused necrosis at the injected site of guinea-pig and eel.

In other pathogenic organisms such as Pseudomonas aeruginosa, ${ }^{18-20}$ Aeromonas salmonicida, ${ }^{21)}$ and a fluorescent pseudomonad, ${ }^{22)}$ toxic activities of protease were examined, and they were suspected to be one of the important virulence factors. On the other hand, though $A$. hydrophila is known to produce a large quantity of extracellular protease, the role of the enzyme in disease process has not been investigated yet. WAKABAYASHI et al. ${ }^{13)}$ showed that strains of the high virulent group ( $A$. hydrophila biovar. hydrophila ${ }^{23)}$ ) were also powerful producers of the enzyme and that their culture filtrates caused hemorrhages and mortalities in carp. The present investigation was carried out to clarify the pathogenic activities of the enzyme in disease process.

This paper reports the purification method and some properties of the enzyme as well as toxic activities.

\section{Materials and Methods}

\section{Organism}

A. hydrophila, strain A10, isolated from the intestines of an eel suffering from red disease in 1978, was used in this study. This strain was identified as $A$. hydrophila biovar. hydrophila according to POPOFF and VÉRON, ${ }^{23)}$

\section{Cultivation}

Medium for protease production of the bacteria contains $5 \mathrm{~g}$ of Bacto-pepton (Difco), $3 \mathrm{~g}$ of beef extract (Difco), $10 \mathrm{~g}$ of yeast extract (Difco), and $5 \mathrm{~g}$ of $\mathrm{NaCl}$ per $1000 \mathrm{ml}$ of distilled water, and $\mathrm{pH}$ was adjusted to 7.2. Small volume of fresh culture was inoculated to $1000 \mathrm{~m} l$ of this medium in a $5 l$ Erlenmeyer flask and incubated at $27^{\circ} \mathrm{C}$ on a rotary shaker (100 rev./min). After $48 \mathrm{~h}$, cells

*1 Department of Fisheries, Faculty of Agriculture, University of Tokyo, Bunkyo, Tokyo 133, Japan (金井 欣也・若林久呞: 東京大学農学部水産学科).

*2 Present address, Faculty of Fisheries, The University of Nagasaki, Bunkyo, Nagasaki 852, Japan (現住 所: 長崎大学水産学部). 
were removed by centrifugation, and the supernatant fluid was sterilized by passing through a membrane filter (Millipore Corp., pore size, 0.45 $\mu \mathrm{m})$.

\section{Purification Procedure}

The culture filtrate was added with solid ammonium sulfate to $80 \%$ saturation and allowed to stand overnight at $4{ }^{\circ} \mathrm{C}$. The precipitate was collected by centrifugation and dissolved in $0.02 \mathrm{M}$ Tris- $\mathrm{HCl}$ buffer, $\mathrm{pH} 8.0$. Insoluble materials were removed by a second centrifugation, and acetone, precooled at $-80^{\circ} \mathrm{C}$, was added drop by drop to the clear solution until the concentration reached $60 \%$. After $10 \mathrm{~min}$, the precipitate was collected by centrifugation and dissolved in the Tris- $\mathrm{HCl}$ buffer. Urea was, then, added to this solution to a final concentration of $5 \mathrm{M}$. After incubated for one hour at $37^{\circ} \mathrm{C}$, the solution was dialyzed against $0.01 \mathrm{M}$ phosphate buffer, $\mathrm{pH} 6.0$, at $4^{\circ} \mathrm{C}$ to remove urea. The dialyzed solution was absorbed to a DEAE-Sephadex A-50 column, equilibrated with $0.01 \mathrm{M}$ phosphate buffer. $\mathrm{pH} 6.0$, and eluted with a linear gradient of 0 to $0.3 \mathrm{M} \mathrm{NaCl}$ prepared with the phosphate buffer. Ten-milliliter fractions were collected and the fractions which contained proteolytic activity were pooled and concentrated by adding with ammonium sulfate to $80 \%$ saturation. The precipitate was collected by centrifugation and dissolved in a small volume of $0.1 \mathrm{M}$ Tris- $\mathrm{HCl}$

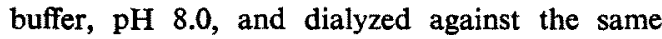
buffer over night. The dialyzed solution was applied to a Sephadex G-100 column $(2.5 \times 90 \mathrm{~cm})$, equilibrated with the Tris- $\mathrm{HCl}$ buffer, and eluted with the same buffer. Pooled fractions which contained proteolytic activity were designated as purified protease and stored at $4^{\circ} \mathrm{C}$.

\section{Measurement of Proteolytic Activity}

Proteolytic activity was determined by the method of MORIHARA et al. ${ }^{24}$ ) with some modifications. Two percent casein solution $(\mathrm{pH}$ 7.4) was prepared with $0.1 \mathrm{M}$ phosphate buffer. A mixture of $1 \mathrm{ml}$ of the casein solution and $1 \mathrm{ml}$ of enzyme solution was incubated at $37^{\circ} \mathrm{C}$ for $10 \mathrm{~min}$, and $6 \mathrm{ml}$ of TCA solution ( $0.1 \mathrm{~m}$ trichloroacetic acid, $0.2 \mathrm{M}$ sodium acetate, and $0.2 \mathrm{M}$ acetic acid) were added to it to terminate the reaction. The tyrosine released from casein was measured spectrophotometrically at $670 \mathrm{~nm}$. The activity was expressed as $\mu \mathrm{g}$ of tyrosine released per min per $\mathrm{m} l$ of enzyme solution.

\section{Electrophoresis}

Disc electrophoresis was carried out as described by DAVIS, ${ }^{25)}$ using $7.5 \%$ gels with a constant current of $2 \mathrm{~mA}$. Protein bands were visualized by staining with $1 \%$ amido black $10 \mathrm{~B}$.

SDS-polyacrylamide electrophoresis for the molecular weight determination was carried out by the method of WEBER and OsBoRn, ${ }^{26)}$ using $10 \%$ gels with a constant current of $8 \mathrm{~mA}$ per tube. Protein bands were visualized by staining with $0.25 \%$ coomassie brilliant blue. Lysozyme, trypsinogen, pepsin, egg albumin, and bovine serum albumin were used as molecular weight markers.

\section{Immunodiffusion and Immunoelectrophoresis}

Rabbit antiserum was prepared by injecting subcutaneously with $1 \mathrm{mg}$ of purified protease mixed with Freund's incomplete ajuvant, twice at one month interval, followed by an injection of $1 \mathrm{mg}$ antigen without ajuvant.

Agarose double diffusion was performed by the method of OUCHTERLONY. ${ }^{27)}$ Immunoelectrophoresis was carried out in $1.0 \%$ agarose with $0.06 \mathrm{M}$ barbital buffer, pH 8.6. Samples were electrophoresed for $90 \mathrm{~min}$ with a constant voltage of $50 \mathrm{~V}$.

\section{Protein Measurement}

Protein content was measured by the method of LOWRY et al., ${ }^{28)}$ using bovine serum albumin as standard.

\section{Toxicity Test}

Lethal activity for fish was examined with carp. Twofold serial dilutions of the enzyme were prepared in $0.05 \mathrm{M}$ phosphate buffer, $\mathrm{pH} 7.4$, and each dilution was injected intraperitoneally to carp ( 30 to $50 \mathrm{~g}$ ) with a dosage of $2 \mathrm{ml}$ per $100 \mathrm{~g}$ body weight.

Dermonecrotic activity was studied in guineapig skin. Each dilution prepared as above was injected intracutaneously with a dosage of $0.1 \mathrm{ml}$.

\section{Results}

\section{Relationship between Cultivation Time and the Pro- duction of Protease}

As shown in Fig. 1, protease was actively released to the culture medium during the mid to late logarismic phase, and the maximal activities were maintained from 30 to 70 hours after inoculation. Toxicity of the culture filtrate was intensified with 


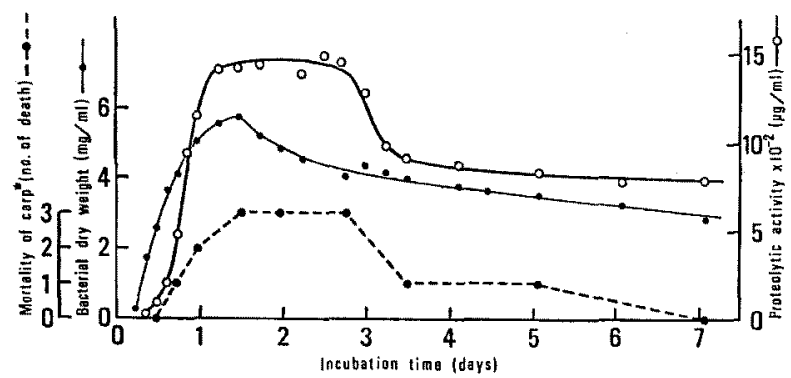

Fig. 1. Relationship among bacterial growth, production of extracellular protease, and the toxicity of culture filtrate.

* Each sample was injected to three carps intraperitoneally, and the mortality was expressed as number of deaths.

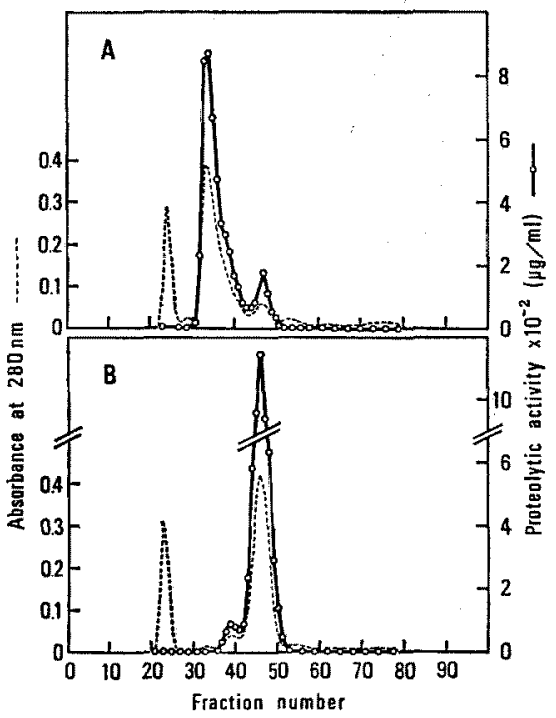

Fig. 2. Elution of several molecular forms of the protease of $A$. hydrophila by gel filtration on Sephadex G-100. The column $(2.5 \times 83 \mathrm{~cm})$ was equilibrated with $0.1 \mathrm{M}$ Tris- $\mathrm{HCl}$ buffer, $\mathrm{pH} 8.0$, containing $0.15 \mathrm{M} \mathrm{NaCl}$. A: Sample was prepared from the culture filtrate by ammonium sulfate precipitation ( $80 \%$ sat.) followed by acetone precipitation (acetone $50 \%$ ), and dialyzed against the Tris buffer overnight. B: Sample was prepared by the same manner as A except for dialyzing against $0.01 \mathrm{M}$ phosphate buffer, $\mathrm{pH} 8.0$, for 4 days before dialysis against the Tris buffer.

the bacterial growth, and seemed to corelate with the proteolytic activity. Hemolytic activity was detected at the early logarismic phase (9 to $18 \mathrm{~h}$ ), but soon disappeared.

\section{Purification}

In the preliminaly experiment proteolytic acti-

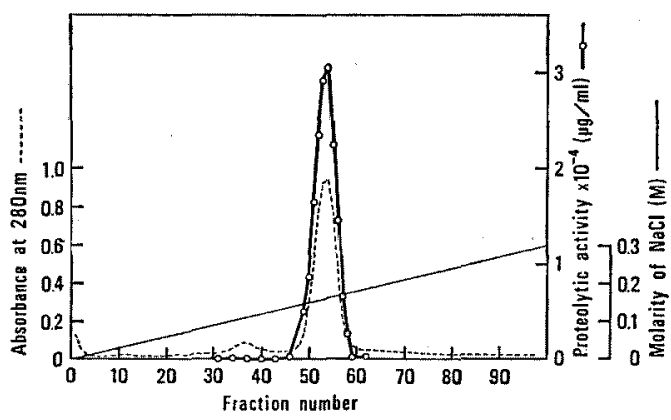

Fig. 3. Column chromatography of the partially purified protease of $A$. hydrophila on DEAESephadex A-50.

The column $(1.5 \times 18 \mathrm{~cm})$ was equilibrated with $0.01 \mathrm{M}$ phosphate buffer, $\mathrm{pH}$ 6.0. After protease solution was charged, elution was performed with increasing molarities of $\mathrm{NaCl}$ in $0.01 \mathrm{M}$ phosphate buffer, $\mathrm{pH} 6.0$, and $10 \mathrm{~m} l$ fractions were collected.

vity of the culture filtrate was separated into two peaks by gel filtration (Fig. 2A). When a sample was dialyzed for a long period (about 4 days) at $\mathrm{pH} 8.0$, the first protease peak had disappeared, and $a$ minor protease peak became visible between the two peaks (Fig. 2B). These elution patterns indicated that the first protease peak was shifted to the third protease peak. This speculation was supported by re-gel filtration. The second peak was also found to be shifted to the third peak, while the third peak was eluted at the same position.

Shifting to the third peak occurred rapidly by urea treatment. In this study urea was also effective to denature most proteins except the protease, and, therefore, this step resulted in a good separation of the protease in the following ionexchange chromatography. As shown in Fig. 3, 
Table 1. Purification of the protease of $A$. hydrophila

\begin{tabular}{lrccccc}
\hline \multicolumn{1}{c}{ Purification step } & $\begin{array}{c}\text { Volume } \\
(\mathrm{m} l)\end{array}$ & $\begin{array}{c}\text { Proteolytic } \\
\text { activity } \\
(\mu \mathrm{g} / \mathrm{m} l)\end{array}$ & $\begin{array}{c}\text { Total } \\
\text { activity } \\
\left(\times 10^{3} \mu \mathrm{g}\right)\end{array}$ & $\begin{array}{c}\text { Protein } \\
(\mathrm{mg} / \mathrm{m} l)\end{array}$ & $\begin{array}{c}\text { Specific } \\
\text { activity } \\
(\mu \mathrm{g} / \mathrm{mg})\end{array}$ & $\begin{array}{c}\text { Yield } \\
(\%)\end{array}$ \\
\hline Culture filtrate & 2000 & 1950 & 3900 & 4.9 & 398 & 100 \\
$\left(\mathrm{NH}_{4}\right)_{2} \mathrm{SO}_{4}$ precipitation & 100 & 32000 & 3200 & 4.9 & 6531 & 82 \\
Acetone precipitation & 30 & 103000 & 3090 & 8.4 & 12262 & 79 \\
Urea treatment & 50 & 57000 & 2850 & 3.9 & 14615 & 73 \\
DEAE-Sephadex A-50 & 98 & 20200 & 1980 & 1.05 & 19238 & 51 \\
Sephadex G-100 & 32 & 43000 & 1376 & 1.72 & 25000 & 35 \\
\hline
\end{tabular}

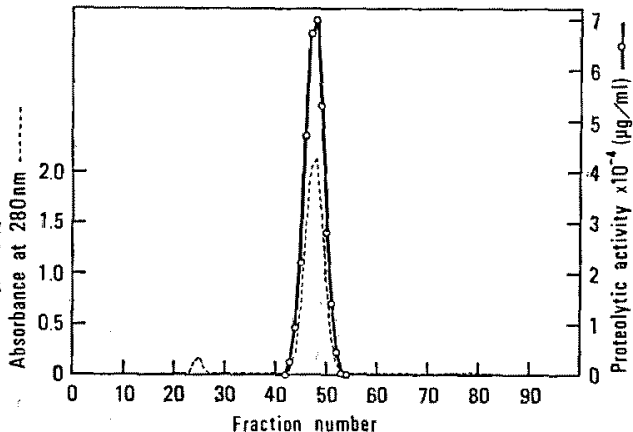

Fig. 4. Gel filtration of the protease of $A$, hydrophila on Sephadex G-100.

The column $(2.5 \times 83 \mathrm{~cm})$ was equilibrated with $0.1 \mathrm{M}$ Tris-HCl buffer, $\mathrm{pH}$ 8.0. Elution was performed with the Tris buffer, and fractions, $4 \mathrm{ml}$ each, were collected at a flow rate of $10 \mathrm{~m} l$ per hour.

protease was eluted from a DEAE-Sephadex column with $0.16 \mathrm{M} \mathrm{NaCl}$. Recovery and the specific activity at each step were summarized in Table 1. Pooled fractions from a Sephadex G100 column (Fig. 4) contained $1.72 \mathrm{mg}$ protein per $\mathrm{ml}$ with a yield of $35 \%$.

Purified protease migrated as a single band in $7.5 \%$ polyacrylamide gels. The molecular weight determined by SDS-polyacrylamide gel electrophoresis was approximately 57,500, and approximately 33,000 by chromatography on Sephadex G-100.

\section{Properties of the Protease}

The optimum $\mathrm{pH}$ for the enzyme activity was 7.5 to 8.0 in $0.1 \mathrm{M}$ phosphate buffer and 8.0 to 8.5 in $0.1 \mathrm{M}$ glycine- $\mathrm{NaOH}$ buffer. The protease was stable at pH 6 to 10 , determined by using $0.05 \mathrm{M}$ acetate at $\mathrm{pH} 4$ to $5,0.05 \mathrm{M}$ phosphate at $\mathrm{pH} 6$ to 8 , and $0.05 \mathrm{M}$ glycine at $\mathrm{pH} 9$ to 12 . The enzyme activity was stable for one hour at $50^{\circ} \mathrm{C}$, but at $60{ }^{\circ} \mathrm{C} 30 \%$ of the activity were lost. The protease

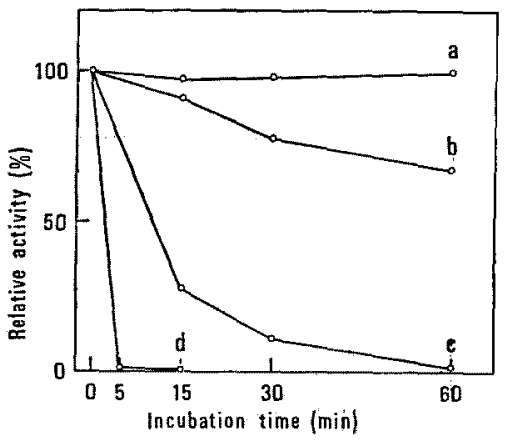

Fig. 5. Effect of heating on the stability of the protease of $A$. hydrophila.

a, $50^{\circ} \mathrm{C} ; \mathrm{b}, 60^{\circ} \mathrm{C} ; \mathrm{c}, 70^{\circ} \mathrm{C} ; \mathrm{d}, 80^{\circ} \mathrm{C}$.

was completely inactivated by heating for one hour at $70^{\circ} \mathrm{C}$ or for $5 \mathrm{~min}$ at $80^{\circ} \mathrm{C}$ (Fig: 5 ). The enzyme activity was strongly inhibited by $\mathrm{Ni}^{2+}, \mathrm{Cu}^{2+}, \mathrm{Cd}^{2+}$, and $\mathrm{Hg}^{2+}$. Chelating agents such as EDTA and $o$-phenanthroline were also inhibrtory (Table 2).

\section{Serological Analysis}

In double diffusion agar, purified protease formed a single precipitin line with the homologous rabbit antiserum. The culture filtrate also formed a single precipitin line coalescing with that of purified protease (Fig. 6a). In immunoelectrophoresis the culture filtrate was separated into two lines, one of which migrated to the position of purified protease and the other did not move during electrophoresis. The two lines, however, seemed to be serologically identical, because they were coalescing each other (Fig. 6b).

\section{Toxicity}

The minimum lethal dose in carp was $200 \mu \mathrm{g}$ per $100 \mathrm{~g}$ body weight by intraperitoneal injection. Most death occurred within 24 hours, and upon autopsy extensive hemorrhages in the abdominal cavity were observed. Intramuscular injection to carp caused hemorrhage and colliquative necrosis 
Table 2. Effect of metal ions and inhibitors on the proteolytic activity of the protease of $A$. hydrophila*

\begin{tabular}{|c|c|c|}
\hline Metal ion & Concentration & $\begin{array}{l}\text { Relative } \\
\text { activity }\end{array}$ \\
\hline None & - & $100 \%$ \\
\hline $\mathrm{Mg}^{2+}$ & $1 \mathrm{~mm}$ & $91 \%$ \\
\hline $\mathrm{Ca}^{2+}$ & $1 \mathrm{~mm}$ & $88 \%$ \\
\hline $\mathrm{Mn}^{2+}$ & $1 \mathrm{~mm}$ & $69 \%$ \\
\hline $\mathrm{Fe}^{2+}$ & $1 \mathrm{~mm}$ & $41 \%$ \\
\hline $\mathrm{Co}^{2+}$ & $1 \mathrm{~mm}$ & $42 \%$ \\
\hline $\mathrm{Ni}^{2+}$ & $1 \mathrm{~mm}$ & $9 \%$ \\
\hline $\mathrm{Cu}^{2+}$ & $1 \mathrm{~mm}$ & $7 \%$ \\
\hline $\mathrm{Zn}^{2+}$ & $1 \mathrm{~mm}$ & $43 \%$ \\
\hline $\mathrm{Cd}^{2+}$ & $1 \mathrm{~mm}$ & $17 \%$ \\
\hline $\mathrm{Ba}^{2+}$ & $1 \mathrm{~mm}$ & $85 \%$ \\
\hline $\mathrm{Hg}^{2+}$ & $1 \mathrm{~mm}$ & $6 \%$ \\
\hline \multicolumn{3}{|l|}{ Inhibitor } \\
\hline EDTA $2 \mathrm{Na}$ & $1 \mathrm{~mm}$ & $9 \%$ \\
\hline$o$-phenanthroline & $1 \mathrm{~mm}$ & $3 \%$ \\
\hline Cysteine & $1 \mathrm{~mm}$ & $64 \%$ \\
\hline Sodium thioglycolate & $1 \mathrm{~mm}$ & $88 \%$ \\
\hline $\begin{array}{l}\text { Soybean trypsin } \\
\text { inhibitor }\end{array}$ & $0.6 \mathrm{mg} / \mathrm{m} l$ & $98 \%$ \\
\hline
\end{tabular}

* Metal ion (chloride form) or inhibitor was added to enzyme solution in $0.05 \mathrm{M}$ Tris- $\mathrm{HCl}$ buffer, $\mathrm{pH} 8.0$, and the mixture was incubated for one hour at $37^{\circ} \mathrm{C}$ before measuring the remained activity.

at the injection site (Fig. 7).

When the protease was injected into guinea-pig skin, intracutaneous hemorrhage was observed within $15 \mathrm{~min}$, and the hemorrhagic region became

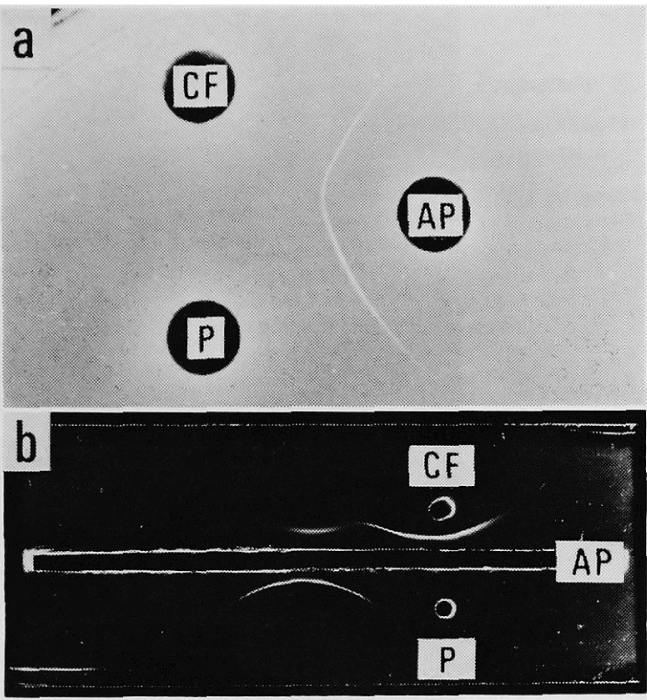

Fig. 6a. Immunodiffusion patterns of the crude and purified protease of $A$. hydrophila.

b. Immunoelectrophoresis patterns of the crude and purified protease of $A$. hydrophila.

AP, Rabbit anti-protease serum; P, Purified protease; $\mathrm{CF}$, Culture filtrate.

necrotic by $24 \mathrm{~h}$ after injection. The minimum dermonecrotic dose was $3.13 \mu \mathrm{g}$, and the degrees of dermonecroses produced by purified protease were almost comparable to those produced by the culture filtrate when both injectants were adjusted to be equal in the enzyme activity (Fig. 8).

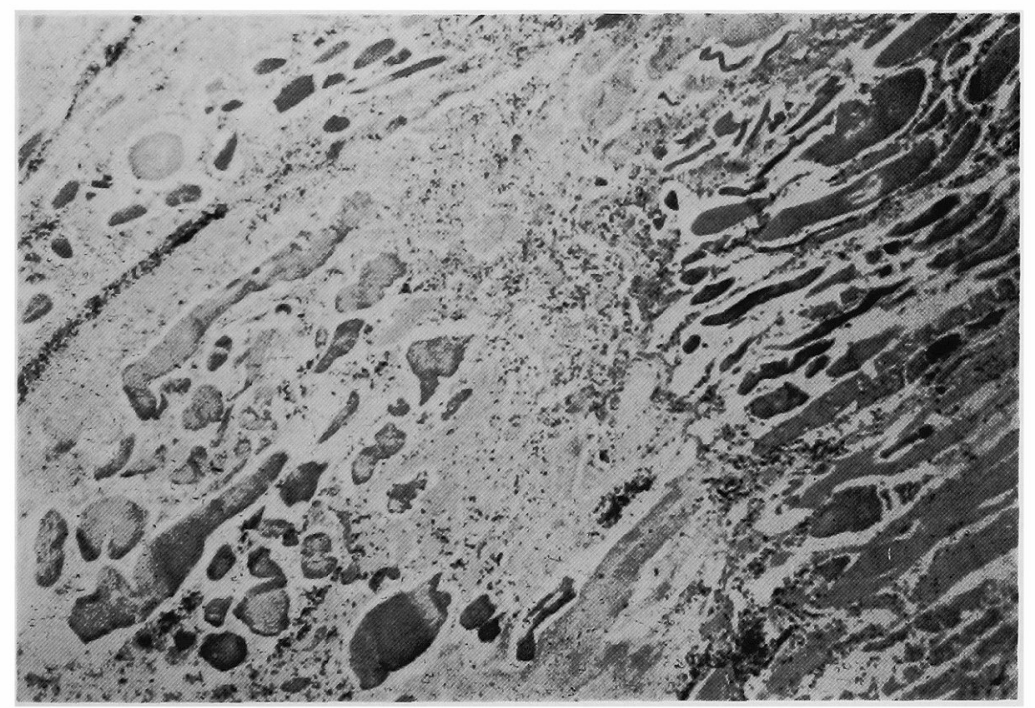

Fig. 7. Histological section of the muscle of carp injected intramuscularly with $15 \mu \mathrm{g}$ of the protease of A. hydrophila. Hemorrhage and colliquative necrosis were observed arround the injection site. H-E stain. 


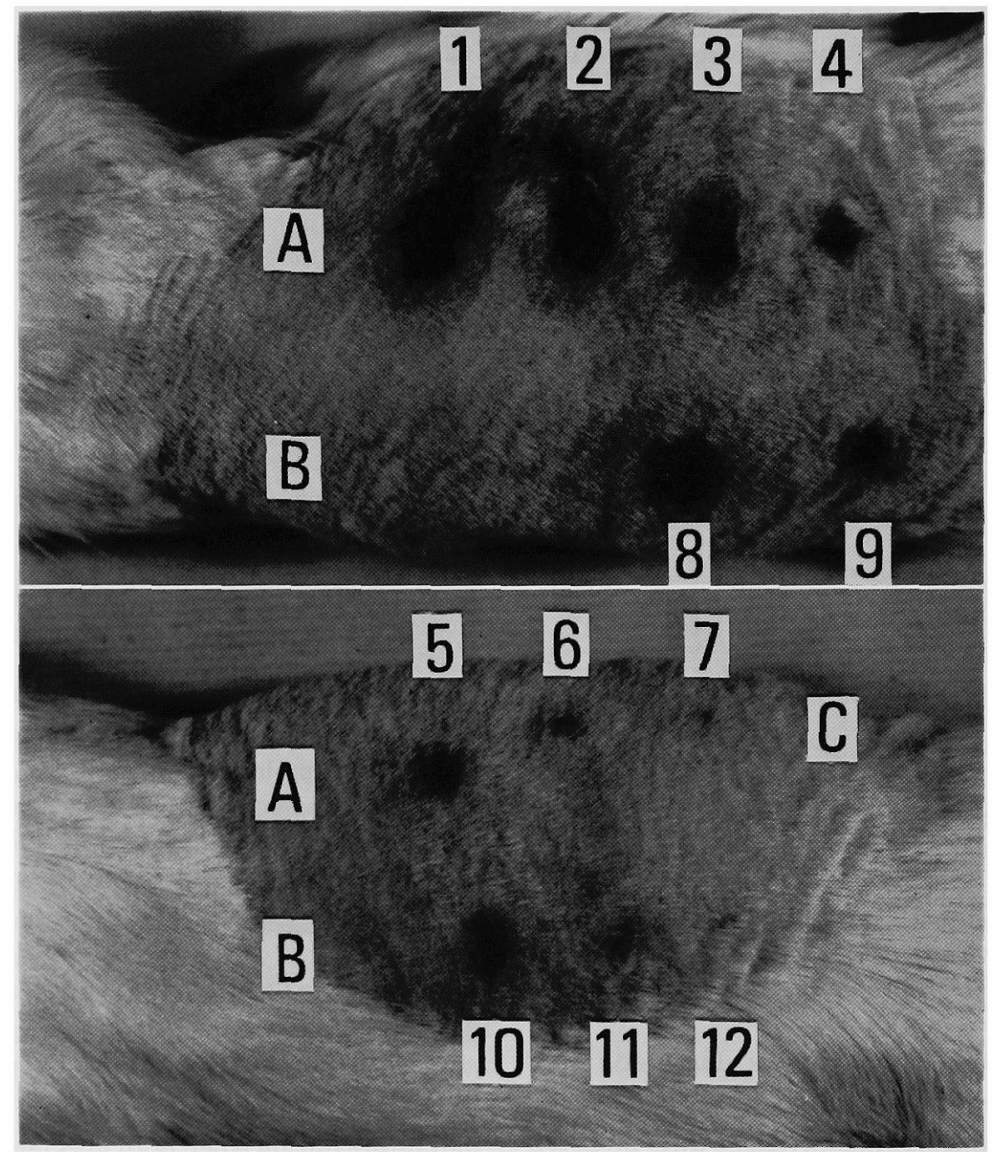

Fig. 8. Lesions in the dorsal skin of guinea-pigs produced by the protease and the culture filtrate of $A$. hydrophila.

The photograph was taken 48 hours after injections. A, Protease: $1,100 \mu \mathrm{g} ; 2,50 \mu \mathrm{g} ; 3$, $25 \mu \mathrm{g} ; 4,12.5 \mu \mathrm{g} ; 5,6.25 \mu \mathrm{g} ; 6,3.13 \mu \mathrm{g} ; 7,1.56 \mu \mathrm{g}$. B, Culture filtrate: Lesions of $8,9,10$, 11 , and 12 were produced by the culture filtrate possessed the proteolytic activity corresponding to $25 \mu \mathrm{g}, 12.5 \mu \mathrm{g}, 6.25 \mu \mathrm{g}, 3.13 \mu \mathrm{g}$, and $1.56 \mu \mathrm{g}$ of the protease, respectively. C, Control.

\section{Discussion}

DAHLE $^{2 \theta)}$ showed that $A$. liquefaciens $(=A$. hydrophila) produced two kinds of proteases. They were designated as proteinase $\mathrm{A}$ and $\mathrm{B}$, and were distinguished each other by molecular weight, immunoelectrophoretical mobility, and some other enzymatic properties, though the properties of proteinase B were examined using the corresponding proteinase produced by $A$. salmonicida. ALLAN and STEVenson ${ }^{30)}$ also observed two distinct proteases in gel filtration. In the present study proteolytic activity in the culture filtrate was separated into three components in gel filtration. However, the first and the second components were eluted at the same position as the third one when chromatography was repeated. In immunoelectrophoresis the protease in the culture filtrate was separated into two components as shown by DAHLE, ${ }^{29)}$ but they were serologically identical, because the two precipitin lines were coalescing each other. These facts suggested that the protease of A. hydrophila was essentially one and that some molecular complexes existed together in the culture filtrate. Similar results have been described for several bacterial enzymes and toxins, e.g. $\alpha$-toxin of Clostridium perfringens, ${ }^{31)}$

MATSUdA and YonedA ${ }^{32)}$ applied urea to dissociate tetanus toxin into two active fragments. In this study, too, urea treatment to the crude enzyme solution was rather effective, because by this treatment the molecular complexes were 
rapidly dissociated without lowering the specific activity or altering the properties. This step led to saving of time and a high yield in purification.

The molecular weight of the preparation was estimated to be 57,500 by SDS-polyacrylamide gel electrophoresis, and was estimated to be 33,000 by chromatography on Sephadex G-100. There was a great difference between both values, but the chromatographic value agreed with the result of Gross and CoLEs. ${ }^{33)}$ However, since the molecular weights of macromolecules calculated from the eluted position in gel filtration are sometimes misestimated ${ }^{34)}$ the exact value of the protease of A. hydrophila may be closer to the electrophoretic value rather than the chromatographic value. As discussed on $\alpha$-toxin of $C$. perfringens, ${ }^{31)}$ the protease may have a compact molecular shape or may interact with dextran gel. Other properties, that is, $\mathrm{pH}$ optimum, heat stability, and inhibition by chelating agents were also similar to the results of Gross and Coles..$^{39}$ Activation by $\mathrm{Co}^{2+}$ or $\mathrm{Fe}^{2+}$ was not observed as described by DAHLE. ${ }^{29)}$

Recently THUNE et al. ${ }^{35)}$ described lethal effects of patially purified proteases of $A$. hydrophila to channel catfish. The present investigation, using purified material, demonstrated that the protease possessed lethal effect to carp and dermonecrotic activity to guinea-pig. Injecting the enzyme to the muscle of carp also caused local hemorrhage and necrosis. These pathogenic effects were quite similar to those observed in the case of $\boldsymbol{A}$. salmonicida ${ }^{21)}$ and $\boldsymbol{P}$. aeruginosa. ${ }^{18)}$

Among toxic substances produced by $A$. hydrophila, hemolysin was most vigorously investigated and showed to possess cytotoxicity, dermonecrotic activity, and lethal activity to mammalian cells or animals. ${ }^{3)}$ Allan and SteVEnson ${ }^{30)}$ described that the hemolysin was suspected to be an important pathogenic factor also in fish disease, and that the toxicity of the protease could almost eliminated as the culture filtrate prepared from a protease-deficient mutant was as toxic as that from the parent strain. However, from the present result it was obvious that the protease was toxic to fish. The reason why ALLAN and STEvenson overlooked the toxicity of the protease may be due to small amounts of the protease production by their strain. If the protease is produced at the site of infection, destruction of surrounding tissue induced by the protease will support bacterial growth and development of disease, even when it will not act as a lethal factor.

\section{Acknowledgements}

We express our appreciation to Professor S. EgusA, Department of Veterinary, Nippon Veterinary and Zootechnical College, for helpful discussion during the course of this work and for reviewing the manuscript.

\section{References}

1) G.L. Bullock, D.A. Conroy, and S.F. SNIESZKo: Diseases of Fishes, Bacterial Diseases of Fishes, T. F. H. Publications, Hong Kong, 1971, pp. 2141.

2) R. Rosner: Am. J. Clin. Pathol., 42, 402-404 (1964).

3) A. von Graevenity and A.H. Mensch: $N$. Engl. J. Med., 278, 245-249 (1968).

4) A. W. Bernhemer and L. S. Avigad: Infect. Immun., 9, 1016-1021 (1974).

5) S. C. Sanyal, S. J. Singh, P. C. Sen: J. Med. Microbiol., 8, 195-198 (1975).

6) Y. Boulanger, R. Lallier, and G. Cousineau: Can. J. Microbiol., 23, 1161-1164 (1977).

7) A. LJUNGH, B. WRETLIND, and R. MölLBY: Acta path. microbiol. Scand. Sect. B, 89, 387397 (1981).

8) J. T. BUCKLeY, L. N. HALASA, K. D. Lund, and S. MACINTYre: Can. J. Biochem., 59, 430-435 (1981).

9) G. Olivier, R. LALlier, and S. LaRivière: Can. J. Microbiol., 27, 330-333 (1981).

10) W. M. Johnson and H. Lion: Can. J. Microbiol., 27, 1019-1027 (1981).

11) G. Y. JANKov: Bull. Off. int. Epiz., 69, 10851098 (1968).

12) K. A. Lobountzov and N. I. Roudikov: Bull. Off. int. Epiz., 69, 1099-1105 (1968).

13) H. Wakabayashi, K. Kanal, T. C. HsU, and S. EguSA: Fish Path., 15, 319-325 (1981).

14) T. Shumzu: Bull. Japan. Soc. Sci. Fish., 35, 5566 (1969).

15) T. Shumezu: Bull. Japan. Soc. Sci. Fish., 35, 163-172 (1969).

16) T. Shmmzu: Bull. Japan. Soc. Sci. Fish., 35, 423-429 (1969).

17) T. Shrmzu: Bull. Japan. Soc. Sci. Fish., 35, 613618 (1969).

18) K. Kawaharajo, J. Y. Homma, Y. Aoyama, K. OKADA, and K. MORIHARA：Japan.J. Exp. Med., 45, 79-88 (1975).

19) K. Kawaharajo, J. Y. Homma, Y. Aoyama, and K. MoriHaRA: Japan. J. Exp. Med., 45, 89-100 (1975).

20) B. WRETLINd and T. WADStRöM: J. Gen. Microbiol., 103, 319-327 (1977).

21) D. K. SAKaI: Sci. Rep. Hokkaido Fish Hatchery, 33, 55-73 (1978). 
22) M. F. LI and C. Flemming: Can. J. Microbiol, 13, 405-416 (1967).

23) M. Popofr and M. Véron: J. Gen. Microbiol., 94, 11-22 (1976).

24) K. Mormara, H. Tsuzukt, T. Oka, H. Inoue, and M. EbatA： J. Bact., 240, 3295-3304 (1965).

25) B. J. Davis: Ann. N. Y. Acad. Sci., 121, 404-427 (1964).

26) K. Weber and M. Osborn: I. Biol. Chem, 244, 4406-4412 (1969).

27) Ö. OUCHTERLONY: Acta path. microbiol. Scand, 25, 186-191 (1948).

28) O. H. Lowry, N. J. Rosebrough, A. L. FARr, and R. J. RANDALI: J. Biol. Chem., 193, 265-275 (1951).
29) H. K. DAHLE: Acta path. microbiol. Scand., Sect. B., 79, 726-738 (1971).

30) B.J. Allan and R. M. W. Stevenson: Can. J. Microbiol., 27, 1114-1122 (1981).

31) Y. YAMAKAWA and A. OHSAKA: J. Biochem., 81, 115-126 (1977).

32) M. MATSUdA and M. Yoneda: Infect. Immun, 12, 1147-1153 (1975).

33) R. Gross and N. W. Coles: Aust. J. Sci., 31, 330-331 (1968).

34) M. L. Maire, E. Rivas, and J. V. Møller: Anal. Biochem., 106, 12-21 (1980).

35) R. L. Thune, T. E. Graham, L. M. Riddle, and R. L. Amborsky: Trans. Amer. Fish. Soc., 111, 749-754 (1982). 